\title{
Pollen harvest by Apis mellifera L. (Hymenoptera: Apidae) in the Dourados region, Mato Grosso do Sul state (Brazil)
}

\author{
Carlos D’Apolito ${ }^{1,4}$, Sheila Magalhães Pessoa $^{2}$, Fátima Cristina de Lazari Manente Balestieri ${ }^{3}$ \\ and José Benedito Perrella Balestieri ${ }^{3}$
}

Recebido em 12/03/2010. Aceito em 12/08/2010

\begin{abstract}
RESUMO - (Pólen coletado por Apis mellifera L. (Hymenoptera: Apidae) na região de Dourados, estado de Mato Grosso do Sul (Brasil)). Apresentamos dados sobre a coleta de pólen por Apis mellifera L. em uma localidade no centro-oeste do Brasil, ainda não estudada. Cargas corbiculares de pólen foram coletadas durante um ano em frente ao ninho, acetolisadas e montadas em lâminas para microscopia óptica. A identificação foi feita por comparação com uma coleção de referência local. Quarenta e dois tipos polínicos foram utilizados pelas abelhas; as famílias mais importantes foram Myrtaceae, Asteraceae, Euphorbiaceae, Brassicaceae e Poaceae. O ranqueamento de importância relativa para gênero/espécie mostrou Eucalyptus (19\%), Raphanus raphanistrum (13\%), Poaceae tipo 2 (7,5\%), Jatropha cf. gossypiifolia (7\%) e Sapium glandulatum (6,5\%). No geral, a maioria dos recursos ( $80 \%)$ não foi utilizada com abundância, e uma minoria (4\%) alcançou valores de 10\%. Dado que a área de estudo não possui uma vegetação natural, mas cultivares, nós indicamos a maioria das espécies identificadas como manejáveis e apontamos que a vegetação ruderal pode ser importante como recurso alimentar para abelhas uma vez que ela ocorreu com frequência no espectro polínico mesmo dentro de uma área completamente cultivada.
\end{abstract}

Palavras-chaves: centro-oeste brasileiro, flora apícola

\begin{abstract}
Pollen harvest by Apis mellifera L. (Hymenoptera: Apidae) in the Dourados region, Mato Grosso do Sul state (Brazil)). We present data on the pollen harvest by Apis mellifera L. at a central-western Brazil site not yet studied. Corbiculae pollen loads were collected during one year in front of the hive, acetolysed and slides mounted for optical microscopy. Identification followed comparisons with a local pollen collection. Forty-two pollen types were utilized by the bee; the most important families were Myrtaceae, Asteraceae, Euphorbiaceae, Brassicaceae and Poaceae. The genus/species level ranking of relative importance showed Eucalyptus (19\%), Raphanus raphanistrum (13\%), Poaceae type 2 (7.5\%), Jatropha cf. gossypiifolia (7\%) and Sapium glandulatum (6.5\%). Overall, the majority of pollen types $(80 \%)$ were not abundantly harvested, and a minority (4\%) reached values of $10 \%$. Given that the study area has cultivated plants and not natural vegetation, we indicate most of the identified species as manageable and point out that weedy vegetation can be an important food source for bees since it frequently occurred in the pollen spectra even within a totally cultivated area.
\end{abstract}

Key words: bee flora, Brazilian center west

\section{Introduction}

Pollen is an essential food element for bees as it is their main protein source (Michener 2000). Flower use by visitors may include the collection of both pollen and nectar, which are some of the ways plants have to guarantee reproduction (Barth 1991; Proctor et al. 1996). This insectplant relationship may go beyond what can be expected and show many details, especially when trophic niches are studied. Every bee has its own behavior. Apis mellifera L. is a generalist collector that effectively seeks out flowering plants, instead of using a few sources (Roubik 1989; Marques-Souza et al. 1993; Carvalho et al. 1999).

The honey bee (Apis mellifera) was introduced in Brazil in 1839 by the priest Antônio Carneiro (Camargo 1972) and since then has been potentially competitive with native bees of Neotropical habitats (Ramalho et al. 1990), mainly after hybridization with introduced African species. Abiotic features can influence the collection and data on the autoecology of bees since collecting behavior, flight activity, distance from the source, abundance and floral preference are important to understand its trophic niche (see Roubik 1989; Wilms et al. 1996; Wilms \& Wiechers, 1997).

Conservation of pollinators has largely been discussed in the Brazilian Pollinators Initiative due mainly to the great concern on how important pollinators are for food production worldwide (Imperatriz-Fonseca et al. 2004). Despite this, studies on flower sources utilized by visitors are scanty in the region where this work was carried out: in a review of melissopalinology surveys made in Brazil, Barth (2004) listed no data for the Central-West region. Actually Pott \& Pott (1986) have studied the bee flora of Pantanal and Manente-Balestieri (2001) the pollen and nectar collected by bees, including Apis mellifera, in Corumbá, both in Mato Grosso do Sul state. These results were not included in Barth's (2004) review because they were not published in scientific periodicals. More recently, some new results have been published by Soares et al. (2007) for Mato Grosso state and Polatto \& Alves (2008) and Vieira et al. (2008) for Mato Grosso do Sul state. Given the lack of data, it is more than evident the need for developing such studies in the region, not only for conservation purposes but also to make scientific knowledge available for Apiculture and Agriculture. The aim of this survey was to identify the bee flora utilized by Apis mellifera for the collection of pollen.

\section{Material and methods}

The study was carried out in the state of Mato Grosso do Sul, region of Dourados municipality ( $22^{\circ} 14^{\prime} \mathrm{S}$ and $54^{\circ} 49^{\prime} \mathrm{W}, 452 \mathrm{~m}$ altitude), on the campus of the Universidade Federal da Grande Dourados (UFGD). Regional

\footnotetext{
Smithsonian Tropical Research Institute (STRI), Ancón, Panamá City, Panamá

Universidade Federal da Grande Dourados, Faculdade de Ciências Agrárias, Dourados, MS, Brazil

Universidade Federal da Grande Dourados, Faculdade de Ciências Biológicas e Ambientais, Laboratório de Abelhas Nativas, Dourados,MS, Brazil

4 Author for correspondence: carlosdapolito@hotmail.com
} 
climate is altitudinal tropical with two seasons, rainy from October to June (mean annual rainfall from 1500 to $1700 \mathrm{~mm}$ ) and a sharp dry season from July to September. The average temperature ranges from 19 to $24^{\circ} \mathrm{C}$ (Mato Grosso do Sul 1990)

Despite the fact that the local vegetation was originally semi-deciduous seasonal forest there is no native forested area on the campus but a few individual trees remain. Rather, there are plenty of monoculture plantations, for instance soya, corn, sunflower and others, an orchard, a medicinal plants garden, horticultural fields and flower gardens.

From August 2005 to July 2006 corbicular pollen loads were sampled from worker bees that were returning from the field into the hive. This was done daily between 10:00 am and 12:00 pm and then samples were subjected to the method of acetolysis (Erdtman 1960), which makes grains hollow and thus more appropriate to study detail. Every single day of collection is a subsample within a month, which made counting grains in the slides unnecessary, as is usually done in surveys where pollen is sampled in pollen storage pots. Measurements of pollen grains followed Erdtman (1952) so as any correlation between grain size and frequency of the collected species could be tested. Plant species were identified according to comparisons of bee pollen slides to the pollen database of the Laboratório de Abelhas Nativas (LAN) of UFGD.

Meteorological data were obtained from the university's meteorological station on the campus and distance to some pollen sources utilized by bees from the hive could easily be calculated as the survey area is floristically homogeneous due to cultivated plants, which made possible and quite accurate the mapping of some plant individuals, except for non-cultivated species, like weeds, and unidentified pollen types. The diversity index used was Shannon $\left(\mathrm{H}^{\prime}\right)$ and a clustering analyses of euclidean distance using Ward's method was performed using the software PAST version 1.89 (Hammer et al. 2001).

\section{Results}

The pollen types collected by Apis mellifera are found in Table 1, they comprise 42 plants belonging to 17 families and five unidentified pollen types. The Myrtaceae family was the most important with only one type (Eucalyptus) while the Asteraceae, Euphorbiaceae, Brassicaceae and Poaceae appear nearly identical in harvest percentage, with eight, four, two and three species respectively. Among these, the most frequent pollen types were Eucalyptus (19\%), Raphanus raphanistrum (13\%), Poaceae type 2 (7,5\%), Jatropha cf. gossypiifolia (7\%) and Sapium glandulatum $(6,5 \%)$. The Poaceae family was considerably representative, with three different species, one of which was utilized by the bees during most of the year (eight months). Our data set reveals $80 \%$ of the species being collected between $0.5 \%$ and $2 \%$, an amount of $16 \%$ being collected between $2.5 \%$ and $7.5 \%$, and only $4 \%$ more than $10 \%$.

A seasonal approach reveals discrepant resource diversities: spring ( 25 pollen types), summer (18 pollen types), autumn (10 pollen types) and winter (12 pollen types). In the spring we point out four predominant pollen types, Emilia sonchifolia, Jatropha cf. gossypiifolia, Sapium glandulatum and Eucalyptus. The summer is represented mainly by Eucalyptus, Jatropha cf. gossypiifolia and Poaceae pollen types. During the winter Eucalyptus and Raphanus raphanistrum are important species. A Poaceae pollen type is the most important in the autumn but no Poaceae type is present in the winter.

Meteorological data and diversity indexes are plotted in Fig. 1. Trends are observed with temperature, precipitation and diversity increasing from August to October, when highest diversity is reached. A contrary trend is found in April and May when lowest diversities are seen. From May to July the three variables behave in the same manner.

Clustering (Fig. 2) divided the entire study period mainly in two major groups. The first is characterized by wintery elements, namely Tropaeolum majus, Raphanus sativus, Raphanus raphanistrum, Vicia sativa and also Helianthus annuus and Eucalyptus. The second clusters March, December and January in one subset with Jatropha cf. gossipiifolia, Ocimun basilicum, Eucalyptus and Poaceae pollen types 1 and 2; the other subset (October, April, February and May) is simply represented by higher percentages of Eucalyptus and Poaceae pollen type 2.

With respect to grain size, the large class obtained $19 \%$, very large $7 \%$ and small and very small only $2.3 \%$ each. The medium class, which comprises axes between 25 and $50 \mu \mathrm{m}$, was the most frequent with 29 pollen types (69\%). The correlation "pollen diameter X frequency" was not significant $\left(\mathrm{r}^{2}=0.086\right)$. The species collected by Apis mellifera in this survey were from a few meters to about 450 meters distant from the hive. The colony hive was placed beside several Eucalyptus trees (i.e. $\sim 0 \mathrm{~m}$ distant), the distance from Raphanus raphanistrum and Raphanus sativus was 275 meters and most of the plants, including for instance the Lamiaceae, Aloysia triphylla, Tropaeolum majus, Citrus, Artocarpus heterophyllus, Jatropha cf. gossypiifolia were about 100 meters away. For Vicia sativa and Helianthus annuus the distance was about 450 meters. We assume weeds were not too far away because they are naturally expected to be more widespread. Indeed, we saw bees on small groupings of Emilia sonchifolia about 100 meters from the hive but we cannot safely infer that location was the source of this pollen since we assumed the collected weeds to be widely distributed over the campus. Among these weeds we can identify the Asteraceae species (except Helianthus annuus and Mikania cordifolia), Mimosa, Sida, Poaceae, Talinum and Richardia brasiliensis. If we consider the distance of such weeds and Eucalyptus is from a few to no more than 50 meters, we turn to have $43.5 \%$ of the total pollen collected at this distance range; $17 \%$ up to 100 meters, $14.4 \%$ up to 275 meters and $6.5 \%$ up to 450 meters. The remaining $18.5 \%$ are unknown.

\section{Discussion}

It is agreed that the spectrum of pollen collection by Apis mellifera tends to present dominant and accessory pollen types. This is seen as we have few pollen types collected more than $10 \%$ and most of them less than that, such results are the same as those reached by Cortopassi-Laurino \& Ramalho (1988) and Vanderhuck (1995), which may be seen as temporary specialization on a floral source (Villanueva-G. \& Roubik 2004). The major dominant types here are Eucalyptus and Raphanus raphanistrum. Many different species of 
Table 1. Pollen types collected by Apis mellifera L. in Dourados (MS), Brazil, and their monthly and annual percentages.

\begin{tabular}{|c|c|c|c|c|c|c|c|c|c|c|c|c|c|c|}
\hline Family & Pollen type & Aug. & Sep. & Oct. & Nov. & Dez. & Jan. & Feb. & Mar. & Apr. & May. & Jun. & Jul. & annual $\%$ \\
\hline Anacardiaceae & Astronium fraxinifolium Schott ex Spreng. & & & & & & & 6,25 & & & & & & 0,50 \\
\hline \multirow[t]{8}{*}{ Asteraceae } & Emilia sonchifolia L. (DC.) & & & 11,1 & 26 & & & & & & & & 6,6 & 4,50 \\
\hline & Helianthus annuus $\mathrm{L}$. & & & & 4,35 & 28,5 & & & & & & 8,3 & 13 & 4,00 \\
\hline & Mikania cordifolia (L. f.) Willd. & & & & & & & 6,25 & 16,6 & & & & & 2,00 \\
\hline & Vernonia Schreb. sp. & & & 5,5 & & & & & & & & & & 0,50 \\
\hline & Asteraceae type 1 & & & & 8,7 & & & & 4,2 & & & & & 1,50 \\
\hline & Asteraceae type 2 & & & & & & & & 4,2 & & & & & 0,50 \\
\hline & Asteraceae type 3 & & & & & & & & & 20 & & & & 0,50 \\
\hline & Asteraceae type 4 & 4,5 & 4,15 & & & & & & & & & & & 1,00 \\
\hline Bignoniaceae & Bignoniaceae type & & & & & & & 18,75 & & & & & 6,6 & 2,00 \\
\hline \multirow[t]{2}{*}{ Brasicaceae } & Raphanus raphanistrum $\mathrm{L}$. & 32 & 4,15 & & & & & & 12,5 & & & 66,7 & 60 & 13,00 \\
\hline & Raphanus sativus $\mathrm{L}$. & 9 & & & & & & & 4,2 & & & & & 1,50 \\
\hline Cecropiaceae & Cecropia Loefl. sp. & & & 5,5 & & & & & & & & & & 0,50 \\
\hline \multirow[t]{4}{*}{ Euphorbiaceae } & Jatropha cf. gossypiifolia & & & & 17,4 & 28,5 & 21,4 & & 16,6 & & & & & 7,00 \\
\hline & Sapium glandulatum (Vell.) Pax & 4,5 & & & 21,7 & 14,2 & & & & & & & & 6,50 \\
\hline & Croton type & & & & 4,35 & 7,1 & & & & & & & & 1,00 \\
\hline & Euphorbia L. & & & & & & & 6,25 & & & & & & 0,50 \\
\hline \multirow[t]{4}{*}{ Fabaceae } & Vicia sativa $\mathrm{L}$. & 13,5 & & & & & & & & & & & 13,3 & 2,50 \\
\hline & Anadenanthera falcata (Benth.) Speg. & & 4,15 & 5,5 & 4,35 & & & & & & & & & 1,50 \\
\hline & Mimosa L. sp. & & & & & & & 6,25 & & & & & & 0,50 \\
\hline & Fabaceae type & & & & 4,35 & & & & & & & & & 0,50 \\
\hline \multirow[t]{4}{*}{ Lamiaceae } & Leonurus sibiricus $\mathrm{L}$. & & 8,3 & 11,1 & & & & & & & & & & 2,00 \\
\hline & Ocimum basilicum $\mathrm{L}$. & & & & & & 7,1 & & 4,2 & & & & & 1,00 \\
\hline & Marsypianthes chamaedrys (Vahl) Kuntze & & & & & & & & 4,2 & & & & & 0,50 \\
\hline & Lamiaceae type & & & & & & & & & 20 & & & & 0,50 \\
\hline \multirow[t]{2}{*}{ Malvaceae } & Sida L. sp. & & & 5,5 & & & & & & & & & & 0,50 \\
\hline & Malvaceae type & & & & & & 7,1 & 6,25 & & & & & & 1,00 \\
\hline Moraceae & Artocarpus heterophyllus Lam. & & 4,15 & 5,5 & & & & & & & & & & 1,00 \\
\hline Myrtaceae & Eucalyptus L’Hér. & 32 & 50 & 16,6 & & & 14,3 & 18,75 & 16,6 & 20 & 55,5 & 8,3 & & 19,00 \\
\hline \multirow[t]{3}{*}{ Poaceae } & Poaceae type 1 & & & 5,5 & & & & & & & & & & 0,50 \\
\hline & Poaceae type 2 & & & & 8,7 & 7,1 & 7,1 & 18,75 & 8,3 & 20 & 44,5 & 8,3 & & 7,50 \\
\hline & Poaceae type 3 & & & & & 7,1 & 35,7 & 12,5 & 4,2 & & & & & 5,00 \\
\hline Portulacaceae & Talinum Adans. sp. & & & 5,5 & & & & & 4,2 & & & & & 1,00 \\
\hline Rubiaceae & Richardia brasiliensis Gomes & & 4,15 & 5,5 & & & & & & & & & & 1,00 \\
\hline Rutaceae & Citrus L. sp. & & & 5,5 & & & & & & & & & & 0,50 \\
\hline Tropaeolaceae & Tropaeolum majus L. & 4,5 & 8,3 & 5,5 & & & & & & & & 8,3 & & 2,00 \\
\hline Verbenaceae & Aloysisa triphylla (L'Hér.) Britton & & & & & & 7,1 & & & & & & & 1,00 \\
\hline Type 1 & Unidentified Type 1 & & 4,15 & & & & & & & & & & & 0,50 \\
\hline Type 2 & Unidentified Type 2 & & 4,15 & & & & & & & & & & & 0,50 \\
\hline Type 3 & Unidentified Type 3 & & 4,15 & & & & & & & & & & & 0,50 \\
\hline Type 4 & Unidentified Type 4 & & & 5,5 & & & & & & 20 & & & & 1,00 \\
\hline Type 5 & Unidentified Type 5 & & & & & 7,1 & & & & & & & & 0,50 \\
\hline Total & & 7 & 11 & 14 & 9 & 7 & 7 & 9 & 12 & 5 & 2 & 5 & 5 & \\
\hline
\end{tabular}




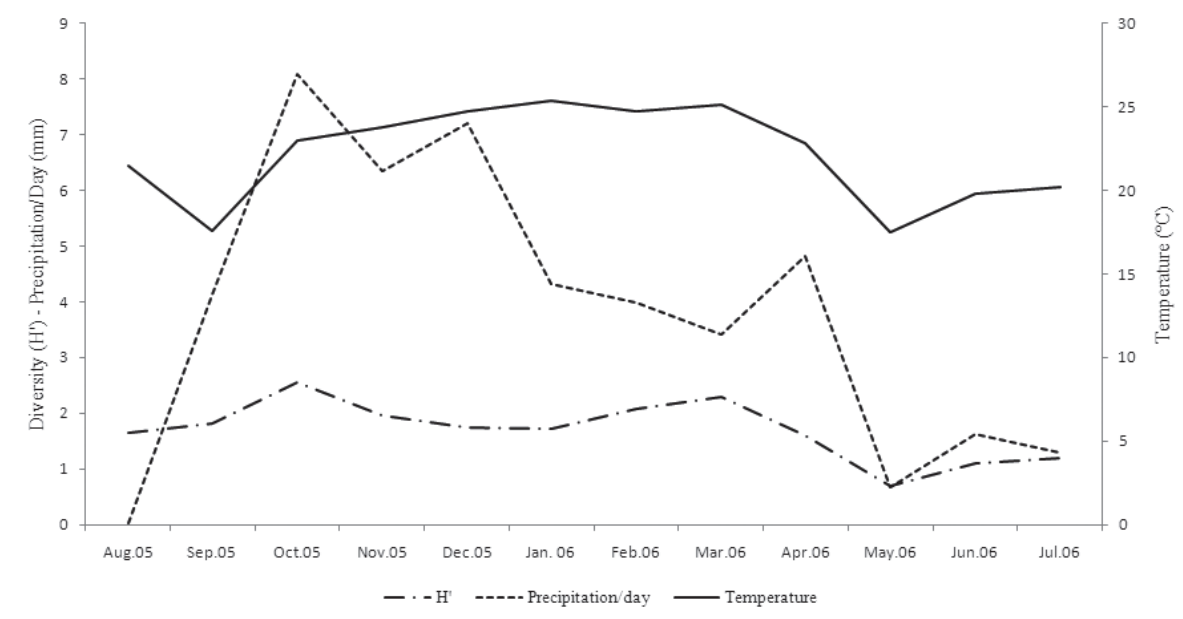

Figure 1. Diversity of pollen collection plotted together with precipitation and temperature data for the study period.

\begin{tabular}{|c|c|c|c|c|c|c|c|}
\hline & & & Simi & arity & & & \\
\hline-27 & -24 & -21 & -18 & -15 & -12 & -9 & -3 \\
\hline
\end{tabular}

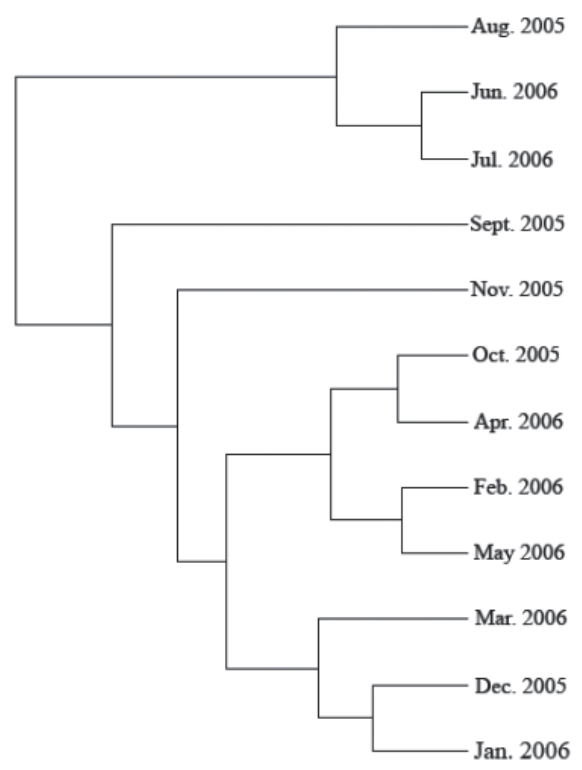

Figure 2. Similarity dendrogram of euclidean distances for the study period.

Eucalyptus are cultivated, including hybrids, and their pollen morphology does not guarantee reliable identification, thus it is very likely that the bees harvested more than one species. In addition, it is foreseeable that the Eucalyptus population within the study site being composed of different species and hybrids allows for a prolonged flowering period. What is more, the proximity of the trees to the hive greatly influences the choice of this pollen source and the floral morphology displays no difficulty for collection. Eucalyptus is also a nectar source for the Africanized honey bee (Santos 1961; Vanderhuck 1995; Bastos et al. 2003).

In contrast to Eucalyptus being collected most of the year (9 months), Raphanus raphanistrum was less constant
(5 months) but abundant when used. This is clear as this species is mainly cultivated during the winter in-between plantations. Indeed, some Cruciferae species (Brassicaceae) are well known as good alternatives for green manuring like Raphanus raphanistrum and Raphanus sativus (Lima et al. 2007) as well as vetch (Vicia sativa). In this period, when food resource availability may decline due to the weather, such species were important options for the honey bee; this is a common practice among beekeepers, who move their hives to places where green manuring is used or where Raphanus sativus is cultivated, despite knowing that such practice may lead to nasturtium-flavored honey, not so appreciated, but which guarantees the hive's survival during low foodresource availability (P.G. Rubert personal communication).

The Asteraceae was the first family in number of species, with eight species found in ten months. Helianthus annuus occurred in November, December, June and July, when it was cultivated on the campus. Emilia sonchifolia was also an important source, mainly in November. The Poaceae types were used during nine months (13\%) and were only absent in the winter. Other weed species were less frequent, namely Mimosa, Richardia brasiliensis, Talinum, Sida and Cecropia. We infer from our data that weeds are important pollen sources for A. mellifera and suggest a hierarchic trend for pollen exploitation of weeds by the honey bee on the campus; (1) Poaceae pollen production is massive and when there are favorable conditions like in the warm, wet summer it is common to see grass aggregates (e.g. colonião) bursting around, which is why no grass pollen was found in the winter. (2) Asteraceae species also spread fast over disturbed areas and similarly to the grasses form large populations, and despite their pollen production not being as massive as that of the Poaceae, they provide bees with good quantities of pollen. (3) A third group is formed by less copious pollen producers and is occasionally harvested. Second-growth forest did not exist on the UFGD campus during the survey period due to regular weeding, thus the intervals from one 
weeding to another only allowed pioneer herbs to succeed and reach flowering.

The pollen types identified here are most commonly found in bee flora inventories, so a brief comparison of the species and genera co-occurring in such surveys is possible. For instance, Machado \& Carvalho (2006) concluded that $60 \%$ of the bee fauna visiting sunflower capitula are Apis mellifera and that it is an effective pollinator of this plant. Marques-Souza et al. (1993) found a great quantity of Cecropia pollen in loads of the honeybee in the Amazon, and argued that the harvest intensity on this plant may be strongly correlated with the presence of disturbed areas. Carvalho et al. (1999) evidenced the Africanized honeybee harvesting Eucalyptus, Sida, some Poaceae, Asteraceae and Mimosoideae. ManenteBalestieri (2001) argued the facility that bees have to harvest Mimosa species, being effective pollinators, what was indeed seen during field observations in this study when Apis mellifera harvested Leucena leucocephala (Lam.) de Wit., though not found in the pollen spectrum. Furthermore, beekeepers already know that honey bees forage on "angicos" (Anadenanthera, Piptadenia, Parapiptadenia) (P.G.Rubert personal communication), once they eventually observe them in the field.

Santos et al. (2005) point out that the pollination of species of the Jatropha genus (Jatropha mutabilis and Jatropha molissima) can be done effectively and occasionally by Apis mellifera and that not only pollen but also nectar is collected. These species like many Euphorbiaceae necessarily need biotic vectors for pollination since the flowers are unisexual, and thus, regarding the importance of Jatropha species as oil producers, it is interesting to learn which species are the most effective pollinators so that management can be better exploited.

According to results of Marques-Souza et al. (1993) and Manente-Balestieri (2001) Arecaceae is an important food resource for Apis mellifera as the dense inflorescences provide pollen in an accessible way and that Curculiondae beetles which visit and effectively pollinate do not show agonistic behavior against bees. Nevertheless, our data set contains no Arecaceae. This may be explained by two main points: in field observations we testified Trigona spinipes bees behaving agonistically against other Apidae on the flowers of a palm species. In addition to this, there were few palm trees flowering during the study period on the campus, and in this case the distance from the hive was approximately 700 meters, which seems not to have been the commonest distance for external activities of $A$. mellifera according to other values found.

Some plants observed by Pott \& Pott (1986) in the Pantanal (vicinity of Corumbá - MS) that were also recorded here include: Astronium, Mikania, Vernonia, Croton, Sapium, Marsypinathes chamaedrys, Mimosa, Talinum, Richardia, and they also point out the importance of cultivars as floral resources for honey bees like Eucalyptus, Jatropha, Citrus and grasses. Also in the Corumbá region, Manente-
Balestieri (2001) registered Apis mellifera on Mimosa, Croton, Jatropha, Talinum, Vernonia and Aloysia.

In a Cerrado area (Cassilândia municipality-MS), Vieira et al. 2008 performed field observations in order to list the plants visited by bees and out of 38 plants visited by the honey bee only Vernonia is a similar result to the data presented in this study. This is interesting because considering the mosaic-like vegetation of the region we clearly see our data are far from a complete range of possible exploited floral sources, regionally speaking. Soares et al, (2007) found Mimosa, Cecropia, Poaceae, Astronium and Vernonia present in honey samples of the Africanized bee in Mato Grosso state.

In the dry vegetations of Bahia, Carvalho \& Marchini (1999) have observed Apis mellifera on flowers of Astronium, Croton, Jatropha, Ocimum, Sida, Mimosa and Talinum. More recent data from the semi-arid region of Bahia (Novais et al. 2009) reveals collection of Croton, Jatropha, Mimosa, Sida and Poaceae, using pollen analysis. In Picos (Piauí state) honey samples contained pollen of Emilia, Mikania, Vernonia, Croton, Sida, Mimosa, Eucalyptus, Poaceae, Richardia and Citrus (Sodré et al. 2008).

In a synthesis of melissopalynological studies in Brazil, Barth (2004) commonly mentions the use of Eucalyptus by the honey bees as both pollen and nectar source. Other cited taxa also present in our dataset are Astronium, Vernonia, Mikania, Cecropia, Croton, Mimosa, Artocarpus, Citrus and Poaceae.

Pollen grains between 25 and $50 \mu \mathrm{m}$ were preferably collected, which is in agreement with results of Pernal \& Currie (2002), who saw a higher collection on particles below $48 \mu \mathrm{m}$. On the other hand, Silva \& Absy (2000) did not find positive correlation (pollen diameter $\mathrm{X}$ frequency) when analyzing pollen from honey samples of Apis mellifera. It seems that a positive correlation is more likely to be found when one analyzes the collection of pollen, not nectar, due to characteristics inherent in pollen handling (Pernal \& Currie 2002), however this was not seen here. In relation to distance from the source plants Paranhos et al. (1997) and Pacheco et al. (1985) saw that the Africanized honey bees prefer to harvest over distances between 50 and 100 meters but can go further. Data presented here are in agreement with this finding.

As shown in Fig.1, the relationship of visited plant numbers and rainfall ranges in direct proportion from August to October, which is the highest rainfall period and in May there is a sharp decrease in all variables. In this month the collection had the lowest richness, possibly due to low temperatures recorded (mean of $17.5^{\circ} \mathrm{C}$ ) and short food source. Thus, the bees based their collection on Eucalyptus and Poaceae, exactly the first and third respectively most collected plants in total. When capturing bees for pollen sampling we noticed there was no activity on very cold days. Contrarily, on warm days after constant rain the bees were extremely active, but on such occasions we waited over an hour and saw no worker bee carrying pollen loads. 
Finally, to get to a bigger picture of the collection dynamics ruling Apis mellifera activities we claim a set of arguments is needed to explain the bee's autoecology. Resource availability, increase in collection efficiency and recruitment, temporary specialization and behavioral features are undoubtedly major traits governing pollen choice (Pernal \& Currie 2002; Villanueva-G. \& Roubik 2004; Ramalho et al. 2007). Hence, it is clear that Apis mellifera behaves in such a way as to satisfy colony needs, with worker bees harvesting most of the time near the hive but extending this harvest distance range when the food source is low or if there is any appreciated plant farther away. As a model of generalist harvesting behavior for bees (Roubik 1989) our results are unsurprisingly in agreement with theory.

Recommendations for regional apiculture may stem from all data that have been accumulating in literature plus the present ones. It is well known that the region is an extremely fragmented landscape of plantations and forest fragments which include semi-deciduous and cerrado vegetation, occasionally called Mata de Dourados. Nevertheless, our dataset better expresses the matrix areas rather than natural vegetation cover. A plant list may not be enough since the area where a bee colony is placed is usually chosen according to plant composition, not the contrary; hence it seems indicatively workable that hives are placed near orchards (e.g. Citrus and Artocarpus) or mixed gardens (e.g. Mikania, R. sativus, Jatropha, Ocimum, Marsypinathes chamaedrys, Talinum, Talinum majus and Aloysia triphylla), plantations (Eucalyptus and Helianthus annuus but also Jatropha, Raphanus sativus and cultivated grasses) and green manuring (Raphanus and Vicia). Obviously we do not deny the importance of natural vegetation and weeds, and indeed recommend land users to avoid weeding when possible, this is indicated by pollen sources that are widespread as pioneer herbs (Asteraceae, Poaceae, Sida, Mimosa, Lamiaceae, Rubiaceae and others) and trees (Cecropia and Sapium). Ruderal vegetation, for instance, is usually found bordering plantations and may thus be additional or accessory pollen sources for honey bees, not to mention nesting sites for native bees. The knowledge of nectar sources will increase the ability for good management, and combining bee products with pollination service will progressively enhance more ecologically fair practices.

\section{Acknowledgements}

We are much indebted to the apiculturist Pio Gardin Rubert for shared experience and providing us the bee colony studied. Alan Sciamarelli is also thanked for the identification of some plant species and so is Marcos Gonçalves Ferreira for the identification of some pollen grains. The manuscript benefited from valuable comments of two anonymous referees.

\section{References}

Barth, F.G. 1991. Insects and flowers - the biology of a partnership Princeton, Princeton University Press.

Barth, O.M. 2004. Mellissopalynology in Brazil: a review of pollen analysis of honeys, propolis and pollen loads of bees. Scientia Agricola 61(3): 342-350.

Bastos, E.M.A.F.; Silveira, V.M. \& Soares, A.E.E. 2003. Pollen Spectrum of Honey Produced in Cerrado Areas of Minas Gerais State (Brazil). Brazilian Journal of Biolog 63(4): 599-615.

Camargo, J.M.F. 1972. Manual de Apicultura. São Paulo, Ed. Agronômica Ceres.

Carvalho, C.A.L. \& Marchini, L.C. 1999. Plantas visitadas por Apis mellifera L. no vale do rio Paraguaçu, Município de Castro Alves, Bahia. Revista Brasileira de Botânica 22(2): 333-338.

Carvalho, C.A.L.; Marchini, L.C. \& Ros, P.B. 1999. Fontes de pólen utilizadas por Apis mellifera L. e algumas espécies de trigonini (Apidae) em Piracicaba (SP). Bragantia 58(1): 49-56.

Cortopassi-Laurino, M. \& Ramalho, M. 1988. Pollen harvest by Africanized Apis mellifera and Trigona spinipes in São Paulo. Botanical and ecological views. Apidologie 19(1):1-24.

Erdtman, G. 1952. Pollen Morphology and Plant Taxonomy. Angiosperms. Stockholm, Almqvist and Wiksell.

Erdtman, G. 1960. The Acetolysis method: in a revised description. Svensk Botanical Tidskrift 54(4): 561-564.

Imperatriz-Fonseca, V.L.; Freitas, B.M.; Saraiva, A.M. \& Dias, B.F.S. 2004. The Brazilian Pollinators Initiative: challenges and opportunities. Proceedings of the 8th IBRA International Conference on Tropical Bees and VI Encontro sobre Abelhas.

Hammer, Ø.; Harper, D.A.T. \& Ryan, P.D. 2001. PAST: Paleontological statistics software package for education and data analysis. Paleontologia Eletronica 4(1): 9p.

Lima, J.D.; Aldrighi, M.; Sakai, R.K.; Soliman, E.P. \& Moraes, W.S. 2007. Comportamento do nabo forrageiro (Raphanus sativus L.) e da nabiça (Raphanus raphanistrum L.) como adubo verde. Pesquisa Agropecuária Tropical 37(1): 60-63.

Machado, C.S. \& Carvalho, C.A.L. 2006. Abelhas (Hymenoptera: Apoidea) visitantes dos capítulos de girassol no recôncavo baiano. Ciência Rural 36(5): 1404-1409.

Manente-Balestieri, F.C.L. 2001. Espécies de plantas visitadas por Melipona favosa orbignyi (Guerin), Trigona chanchamayoensis Schwarz (Hymenoptera: Meliponinae) e Apis mellifera Linneu (Hymenoptera: Apinae) para a obtenção dos recursos florais, em Corumbá, Mato Grosso do Sul. Rio Claro, Tese (Doutorado), UNESP.

Marques-Souza, A.C.; Absy, M.L.; Conde, P.A.A. \& Coelho, H.A. 1993. Dados da obtenção do pólen por abelhas de Apis mellifera no município de Ji-Paraná (RO), Brasil. Acta Amazonica 23(1): 59-76.

Mato Grosso do Sul. 1990. Secretaria de Planejamento e Coordenação Geral. Atlas multireferencial. Campo Grande.

Michener, C.D. 2000. The bees of the world. Baltimore, The Johns Hopkins University Press.

Novais, J.S.; Lima, L.C.L. \& Santos, F.A.R. 2009. Botanical affinity of pollen harvested by Apis mellifera L. in a semi-arid area from Bahia, Brazil. Grana 48(3): 224-234.

Paranhos, B.A.J.; Walder, J.M.M. \& Chaud-Neto, N.J. 1997. Flight Range of Africanized Honeybees, Apis mellifera L. 1758 (Hymenoptera: Apidae) in an Apple Grove. Scientia Agricola 54(1-2): 85-88.

Pacheco, I.A.; Kageyama, P.Y.; Berti-Filho, E. \& Wiendl, F.M. 1985. Efeito de Colméias de Apis mellifera L. em Pomar de Sementes de Eucalyptus saligna Smith. IPEF 29: 11-17.

Pernal, S.F. \& Currie, W. 2002. Discrimination and preferences for pollen-based cues by foraging honeybees, Apis mellifera L. Animal Behaviour 63: 369-390.

Polatto, L.P. \& Alves Jr, V.V. 2008. Utilização dos Recursos Florais pelos Visitantes em Sparattosperma leucanthum (Vell.) K. Schum. (Bignoniaceae). Neotropical Entomology 37(4): 389-398.

Pott, A. \& Pott V.J. 1986. Inventário da Flora Apícola do Pantanal em Mato Grosso do Sul. Corumbá, Embrapa.

Proctor, M.; Yeo, P. \& Lack, A. 1996. The natural history of pollination. London, Harper Collins Publishers. 
Roubik, D.W. 1989. Ecology and natural history of tropical bees. Cambridge, Cambridge University Press.

Ramalho, M.; Kleinert-Giovaninni, A. \& Imperatriz-fonseca, V.L. 1990. Important bee plants for stingless bees (Melipona and Trigonini) and africanized honey bees (Apis mellifera) in neotropical habitats: a Rewiew. Apidologie 21: 469-488.

Ramalho, M.; Silva, M.D. \& Carvalho, C.A.L. 2007. Dinâmica de Uso de Fontes de Pólen por Melipona scutellaris Latreille (Hymenoptera: Apidae): Uma Análise Comparativa com Apis mellifera L. (Hymenoptera: Apidae), no Domínio Tropical Atlântico. Neotropical Entomology 36(1): 38-45.

Santos, C.F.O. 1961. Principais tipos de pólen encontrados em algumas amostras de mel: nota prévia. Revista de Agricultura 36: 93-96.

Santos, M.J.; Machado, I.C. \& Lopes, A.V. 2005. Biologia reprodutiva de duas espécies de Jatropha L. (Euphorbiaceae) em Caatinga, Nordeste do Brasil. Revista Brasileira de Botânica 28(2): 361-373.

Silva, S.J.R \& Absy, M.L. 2000. Análise do pólen encontrado em amostras de mel de A. mellifera L. (Hymenoptera, Apidae) em uma área de savana de Roraima, Brasil. Acta Amazonica 30(4): 579-588.

Soares, E.R.C.; Pestana, D.D.; Barelli, M.A.; Galbiati, C.; Amaral,A.M.; Silva, E.R.G.; Favare, L.G.; Bisler, J.P.; Pereira, R.P. \& Antenor, F.L. 2007. Seleção de espécies melíferas com base na flora da região Sudoeste do Estado de Mato Grosso. Revista Brasileira de Biociências 5(1): 726-728.
Sodré, G.S.; Marchini, L.C.; Moreti, A.C.C.C. \& Carvalho, C.A.L. 2008. Tipos polínicos encontrados em amostras de méis de Apis mellifera em Picos, Estado do Piauí. Ciência Rural 38(3): 839-842.

Vanderhuck, M.G. 1995. Analisis palinologico de la miel y la carga de polen colectada por Apis mellifera en el Suroeste de Antióquia, Colombia. Boletim Museu Entomologia Universidade del Valle 3(2): 35-54.

Vieira, G.H.C.; Marchini, L.C.; Souza, B.A. \& Moreti, A.C.C.C. 2008. Fontes florais usadas por abelhas (Hymenoptera, Apoidea) em área de cerrado no município de Cassilândia, Mato Grosso do Sul, Brasil. Ciência e agrotecnologia 32(5): 1454-1460.

Villanueva-G,R \& Roubik, D.W. 2004. Why are African honey bees and not European bees invasive? Pollen diet diversity in community experiments. Apidologie 35: 481-491.

Wilms, W. \& Wiechers, B. 1997. Floral resource partitioning between native Melipona bees and the introduced Africanized honey bee in the Brazilian Atlantic rain forest. Apidologie 28: 339-355.

Wilms, W.; Imperatriz-Fonseca, V.L. \& Engels, W. 1996. Resources partitioning between highly eusocial bees and possible impact of the introduced Africanized honey bee on native stingless bees in the Brazilian Atlantic rainforest. Studies on Neotropical Fauna \& Environment 31: 137-151. 